\title{
Supplementary Information: Changing mid-twentieth century Antarctic sea ice variability linked to tropical forcing
}

Chris S.M. Turney ${ }^{1,2}$, Andrew Klekociuk ${ }^{3,4}$, Christopher J. Fogwill ${ }^{1,2}$, Violette Zunz ${ }^{5}$, Hugues Goosse ${ }^{6}$, Claire L. Parkinson ${ }^{7}$, Gilbert Compo ${ }^{8,9}$, Matthew Lazzara ${ }^{10,11}$, Linda Keller ${ }^{10}$, Rob Allan ${ }^{12}$, Jonathan G. 5 Palmer $^{1,2}$, Graeme Clark ${ }^{13}$ and Ezequiel Marzinelli ${ }^{13,14,15}$

${ }^{1}$ Climate Change Research Centre, School of Biological, Earth and Environmental Sciences, University of New South Wales, Australia

${ }^{2}$ Palaeontology, Geobiology and Earth Archives Research Centre, School of Biological, Earth and Environmental Sciences,

10 University of New South Wales, Australia

${ }^{3}$ Australian Antarctic Division, 203 Channel Highway, Kingston 7050, Tasmania, Australia

${ }^{4}$ Antarctic Climate \& Ecosystems Cooperative Research Centre, University of Tasmania, Private Bag 80, Hobart, Tasmania 7001

${ }^{5}$ Earth System Science and Departement Geografie, Vrije Universiteit Brussels, Belgium

$15{ }^{6}$ Université catholique de Louvain, Earth and Life Institute, Georges Lemaitre Centre for Earth and Climate Research, Place Pasteur, 3, 1348 Louvain-la-Neuve, Belgium

${ }^{7}$ Cryospheric Sciences Laboratory/Code 615, NASA Goddard Space Flight Center, Greenbelt, MD 20771, USA

${ }^{8}$ Cooperative Institute for Research in Environmental Sciences, University of Colorado, Boulder, CO 80309, USA

${ }^{9}$ Physical Sciences Division, Earth System Research Laboratory, NOAA, Boulder, CO 80305, USA

$20{ }^{10}$ Meteorologist at the Antarctic Meteorological Research Center, Space Science and Engineering Center, University of Wisconsin-Madison, Madison, WI, USA

${ }^{11}$ Department of Physical Sciences, School of Arts and Sciences, Madison Area Technical College, Madison, WI, USA

${ }^{12}$ Met Office Hadley Centre, Exeter, UK

${ }^{13}$ Evolution and Ecology Research Centre, School of Biological, Earth and Environmental Sciences, University of New

25 South Wales, Australia

${ }^{14}$ Sydney Institute of Marine Science, Chowder Bay Road, Mosman NSW 2088, Australia

${ }^{15}$ Centre for Bio-Innovation Science, School of Biological, Earth and Environmental Sciences, University of New South Wales, Australia

Correspondence to: Chris Turney (c.turney@unsw.edu.au)

\section{Contains:}

Section 1: Model description

Figure S1: Spatial correlations between detrended and deseasonalised Nino 3.4 sea surface temperature (Rayner et al., 2003) (October-March) and mean sea level pressure for austral winter (June-August; Panel A), spring (September-November; Panel B), summer (December-February; Panel C) and autumn (March-May; Panel D) using ERA Interim (Dee et al., 2011)

35 for the period 1979-2015. Significance $p_{\text {field }}<0.05$.

Figure S2: Spatial correlations between detrended and deseasonalised extracted southwest Pacific (SWP; $50^{\circ}-60^{\circ} \mathrm{S}, 160-$ $180^{\circ} \mathrm{E}$ ) mean sea level pressure and hemispheric mean sea level pressure for austral winter (June-August; Panel A), spring 
(September-November; Panel B), summer (December-February; Panel C) and autumn (March-May; Panel D) using ERA Interim (Dee et al., 2011) for the period 1979-2015. Significance $p_{\text {field }}<0.05$.

Figure S3: Spatial correlations between detrended and deseasonalised extracted southwest Pacific (SWP; 50 $-60^{\circ} \mathrm{S}, 160-$ $180^{\circ} \mathrm{E}$ ) mean sea level pressure and hemispheric surface zonal wind stress for austral winter (June-August; Panel A), spring

5 (September-November; Panel B), summer (December-February; Panel C) and autumn (March-May; Panel D) using ERA Interim (Dee et al., 2011) for the period 1979-2015. Significance $p_{\text {field }}<0.05$.

Figure S4: Spatial correlations between detrended and deseasonalised extracted southwest Pacific (SWP; 50 $-60^{\circ} \mathrm{S}, 160-$ $180^{\circ} \mathrm{E}$ ) mean sea level pressure and hemispheric surface meridional wind stress for austral winter (June-August; Panel A), spring (September-November; Panel B), summer (December-February; Panel C) and autumn (March-May; Panel D) using

10 ERA Interim (Dee et al., 2011) for the period 1979-2015. Significance $p_{\text {field }}<0.05$.

Figure S5: Spatial correlations between detrended and deseasonalised extracted Amundsen Sea region (AS; 70 $-55^{\circ} \mathrm{S}, 95-$ $135^{\circ} \mathrm{W}$ ) mean sea level pressure and hemispheric surface meridional wind stress for austral winter (June-August; Panel A), spring (September-November; Panel B), summer (December-February; Panel C) and autumn (March-May; Panel D) using ERA Interim (Dee et al., 2011) for the period 1979-2015. Significance $p_{\text {field }}<0.05$.

15 Figure S6: Spatial correlations between detrended and deseasonalised extracted Amundsen Sea region (AS; $70^{\circ}-55^{\circ} \mathrm{S}, 95-$ $135^{\circ} \mathrm{W}$ ) mean sea level pressure and hemispheric surface zonal wind stress for austral winter (June-August; Panel A), spring (September-November; Panel B), summer (December-February; Panel C) and autumn (March-May; Panel D) using ERA Interim (Dee et al., 2011) for the period 1979-2015. Significance $p_{\text {field }}<0.05$.

Figure S7: Spatial correlations between detrended and deseasonalised extracted Amundsen Sea region $\left(\mathrm{AS} ; 70^{\circ}-55^{\circ} \mathrm{S}, 95-\right.$ $20135^{\circ} \mathrm{W}$ ) mean sea level pressure and hemispheric surface meridional wind stress for austral winter (June-August; Panel A), spring (September-November; Panel B), summer (December-February; Panel C) and autumn (March-May; Panel D) using ERA Interim (Dee et al., 2011) for the period 1979-2015. Significance $p_{\text {field }}<0.05$.

Figure S8: Spatial correlations between detrended and deseasonalised extracted southwest Pacific (SWP; 50 -60 S, 160 $180^{\circ} \mathrm{E}$ ) mean sea level pressure and National Snow and Ice Data Center (NSIDC) sea-ice concentration data 25 (https://nsidc.org/data) for austral winter (June-August; Panel A), spring (September-November; Panel B), summer (December-February; Panel C) and autumn (March-May; Panel D) using ERA Interim (Dee et al., 2011) for the period 19792015. Significance $p_{\text {field }}<0.05$.

Figure S9: Spatial correlations between detrended and deseasonalised extracted Amundsen Sea region $\left(\mathrm{AS} ; 70^{\circ}-55^{\circ} \mathrm{S}, 95-\right.$ $135^{\circ} \mathrm{W}$ ) mean sea level pressure and National Snow and Ice Data Center (NSIDC) sea-ice concentration data 30 (https://nsidc.org/data) for austral winter (June-August; Panel A), spring (September-November; Panel B), summer (December-February; Panel C) and autumn (March-May; Panel D) using ERA Interim (Dee et al., 2011) for the period 19792015. Significance $p_{\text {field }}<0.05$.

Figure S10: Dumont D’Urville (DDU) monthly-resolved wind speed record (knots; Panel A knots) and detrended and deseasonalised spatial correlation with September-November mean sea level pressure (Panel B), meridional (Panel C) and 
zonal wind stress (Panel D) from ERA Interim (Dee et al., 2011), and NSIDC sea ice concentration for the period 19792015. Significance $p_{\text {field }}<0.05$. Location of Cape Denison denoted by 'CD'.

Figure S11: Statistically significant correlation between monthly average wind speeds between Dumont D'Urville and Cape Denison. A description of the dominant katabatic winds across the region are described by Kidson (1946) and Parish and

5 Walker (2006)

Figure S12: Simulated LOVECLIM changes in sea ice extent (solid green line) with $1 \sigma$ envelope (light green) off George V Land $\left(\mathrm{GV} ; 70^{\circ}-60^{\circ} \mathrm{S}, 150^{\circ}\right.$ to $\left.180^{\circ} \mathrm{E}\right)$ for austral winter (June-August; Panel A), spring (September-November; Panel B), summer (December-February; Panel C) and autumn (March-May; Panel D) (Zunz and Goosse, 2015).

Figure S13: Simulated LOVECLIM changes in sea ice extent (solid green line) with $1 \sigma$ envelope (light green) in the west 10 Amundsen Sea (AS; $70^{\circ}-60^{\circ} \mathrm{S}, 100^{\circ}$ to $150^{\circ} \mathrm{W}$ ) for austral winter (June-August; Panel A), spring (September-November; Panel B), summer (December-February; Panel C) and autumn (March-May; Panel D) (Zunz and Goosse, 2015).

References 


\section{Section 1. Model description}

LOVECLIM1.3 includes representations of vegetation (VECODE) (Brovkin et al., 2002), atmosphere (ECBilt2) (Opsteegh et al., 1998), and the ocean and sea ice (CLIO3) (Goosse and Fichefet, 1999). The ocean model is coupled to a sea-ice model with a horizontal resolution of $3^{\circ} \times 3^{\circ}$ and 20 unevenly spaced vertical levels, with the three-level quasi-geostrophic

5 atmospheric model having a horizontal resolution approximating $5.6^{\circ} \times 5.6^{\circ}(\mathrm{T} 21)$. The vegetation component simulates the evolution of trees, grasses and desert, with the same horizontal resolution as ECBilt2. The experiments analysed here cover the period 1850-2009, driven by historic CMIP5 simulations for anthropogenic (greenhouse gas, sulphate aerosols, land use) and natural (solar and volcanic) forcings (Taylor et al., 2011). In order to take into account the long memory of the Southern Ocean, the initial conditions are derived from a numerical experiment covering the years 1-1850 using the same forcings 10 (Goosse and Renssen, 2005). A simulation with data assimilation technique based on particle filtering (Goosse et al., 2006; Dubinkina and Goosse, 2013) and without additional freshwater flux from 1850 to 2009 was analyzed here (DA_NOFWF) (Zunz and Goosse, 2015). The model was forced to follow the observations of surface temperature from the HadCRUT3 dataset (Brohan et al., 2006). 
A.

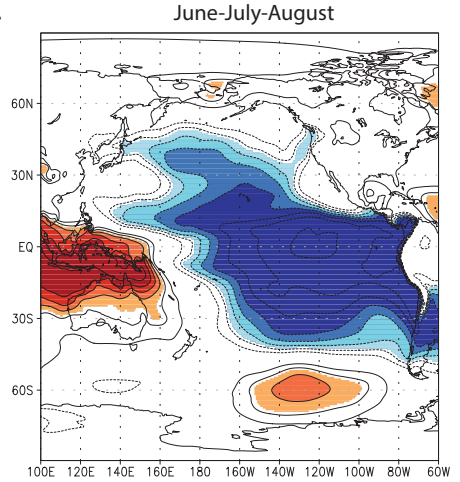

c.

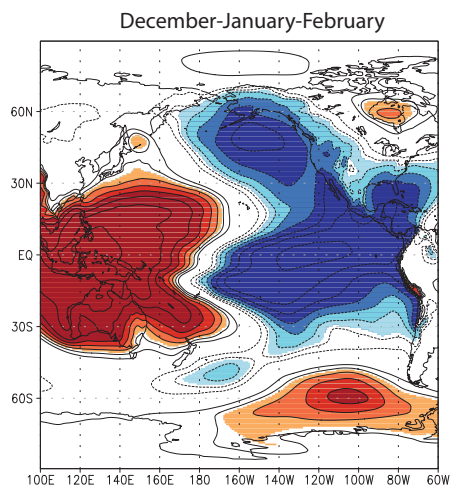

B.

September-October-November

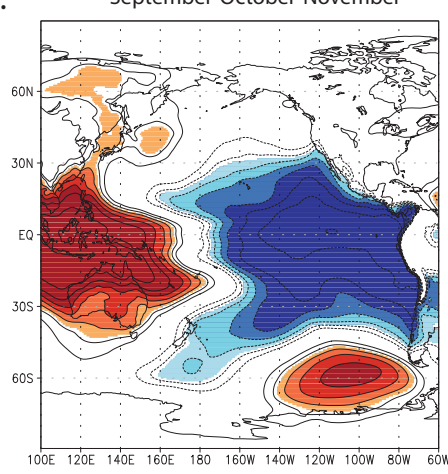

D.

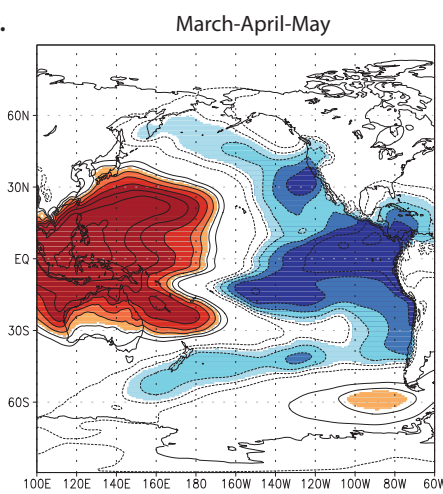

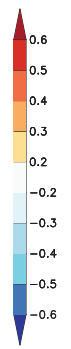

Figure S1: Spatial correlations between detrended and deseasonalised Nino 3.4 sea surface temperature (Rayner et al., 2003) (October-March) and mean sea level pressure for austral winter (June-August; Panel A), spring (September-November; Panel B), summer (December-February; Panel C) and autumn (March-May; Panel D) using ERA Interim (Dee et al., 2011) for the period 1979-2015. Significance $p_{\text {field }}<\mathbf{0 . 0 5}$. 
A.

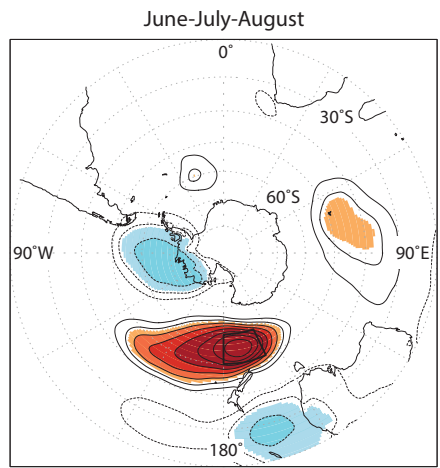

c.

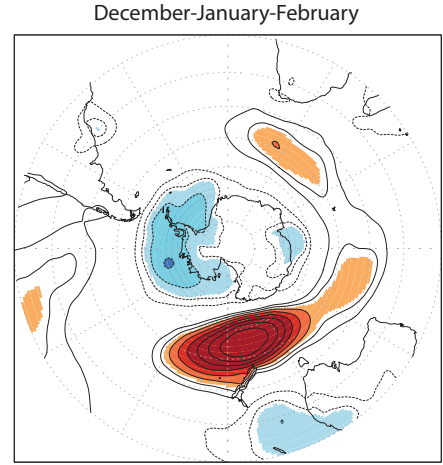

B.
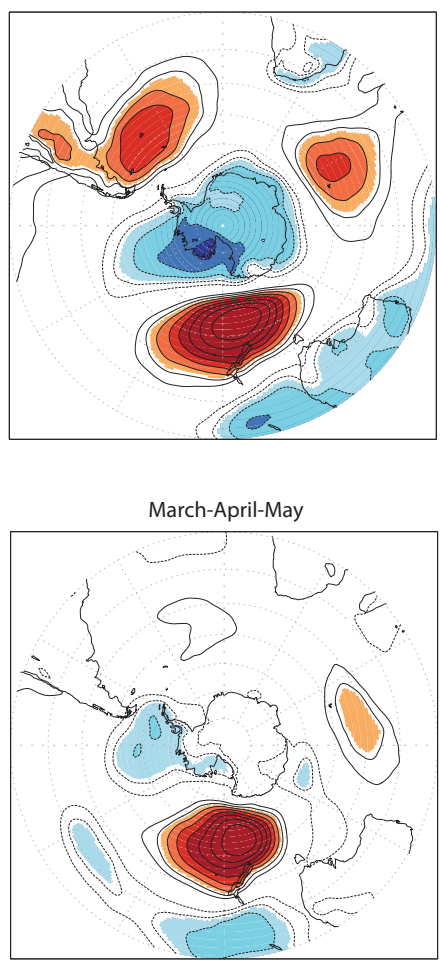

Figure S2: Spatial correlations between detrended and deseasonalised extracted southwest $\mathrm{Pacific}\left(\mathrm{SWP}^{\circ} \mathbf{5 0}^{\circ}-60^{\circ} \mathrm{S}, \mathbf{1 6 0}^{-180^{\circ}} \mathrm{E}^{\circ}\right.$ mean sea level pressure and hemispheric mean sea level pressure for austral winter (June-August; Panel A), spring (SeptemberNovember; Panel B), summer (December-February; Panel C) and autumn (March-May; Panel D) using ERA Interim (Dee et al., 5 2011) for the period 1979-2015. Significance $p_{\text {field }}<0.05$. 
A.

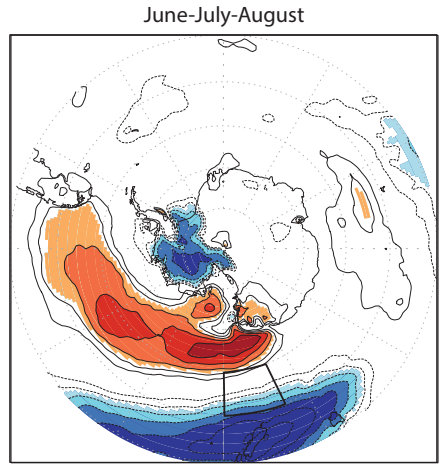

c.

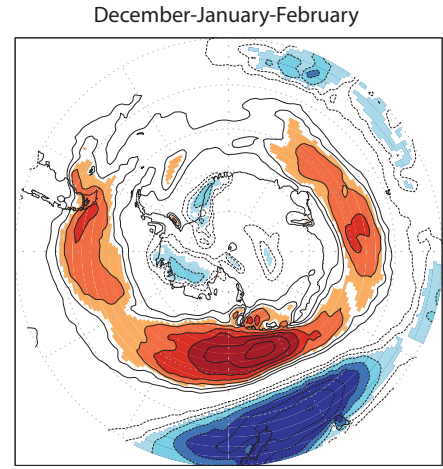

B.

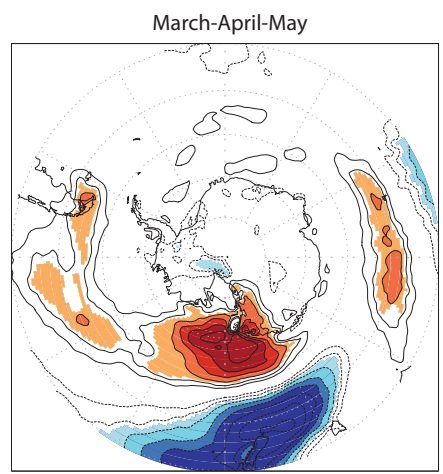

Figure S3: Spatial correlations between detrended and deseasonalised extracted southwest Pacific $\left(\mathrm{SWP}^{\circ} \mathbf{5 0}^{\circ}-60^{\circ} \mathrm{S}, \mathbf{1 6 0}^{-180^{\circ}} \mathrm{E}\right)$ mean sea level pressure and hemispheric surface zonal wind stress for austral winter (June-August; Panel A), spring (SeptemberNovember; Panel B), summer (December-February; Panel C) and autumn (March-May; Panel D) using ERA Interim (Dee et al., 5 2011) for the period 1979-2015. Significance $p_{\text {field }}<0.05$. 
A.

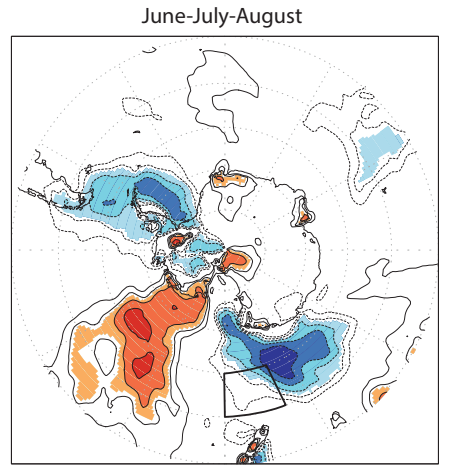

C.

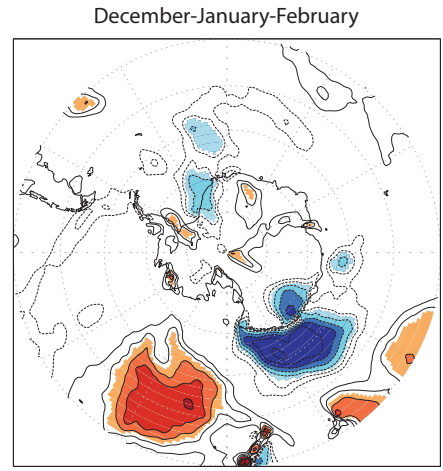

B.
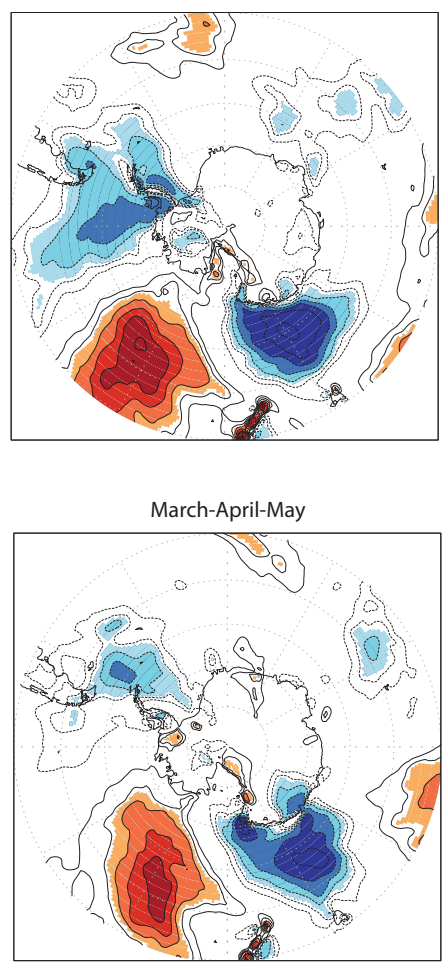

Figure S4: Spatial correlations between detrended and deseasonalised extracted southwest Pacific $\left(\mathrm{SWP}^{\circ} \mathbf{5 0}^{\circ}-60^{\circ} \mathrm{S}, \mathbf{1 6 0}^{-180^{\circ}} \mathrm{E}\right)$ mean sea level pressure and hemispheric surface meridional wind stress for austral winter (June-August; Panel A), spring (September-November; Panel B), summer (December-February; Panel C) and autumn (March-May; Panel D) using ERA Interim 5 (Dee et al., 2011) for the period 1979-2015. Significance $p_{\text {field }}<0.05$. 
A.

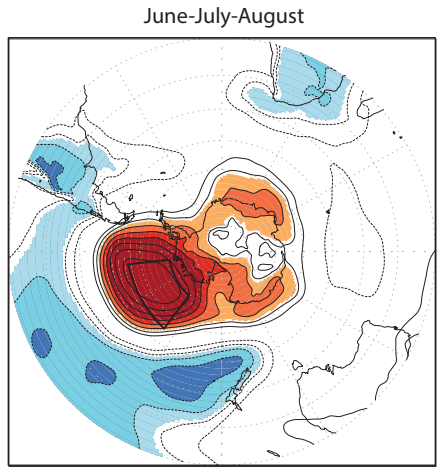

C.

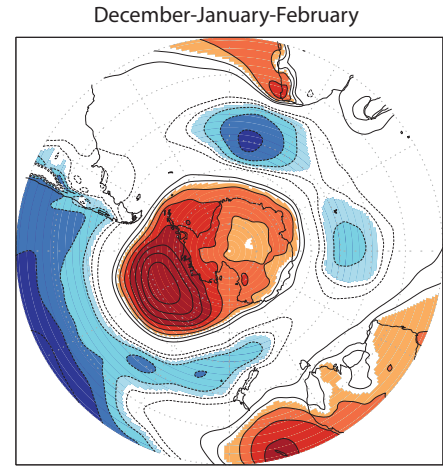

B.
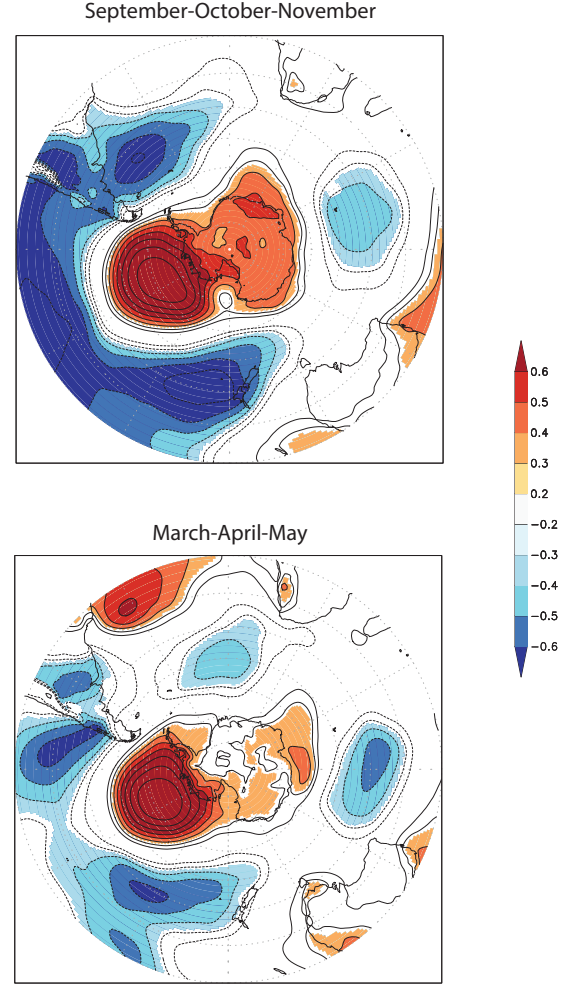

Figure S5: Spatial correlations between detrended and deseasonalised extracted Amundsen Sea region $\left(\mathrm{AS} ; \mathbf{7 0}^{\circ}-55^{\circ} \mathrm{S}, \mathbf{9 5}^{-135} 5^{\circ} \mathrm{W}\right)$ mean sea level pressure and hemispheric surface meridional wind stress for austral winter (June-August; Panel A), spring (September-November; Panel B), summer (December-February; Panel C) and autumn (March-May; Panel D) using ERA Interim 5 (Dee et al., 2011) for the period 1979-2015. Significance $p_{\text {field }}<0.05$. 
A.

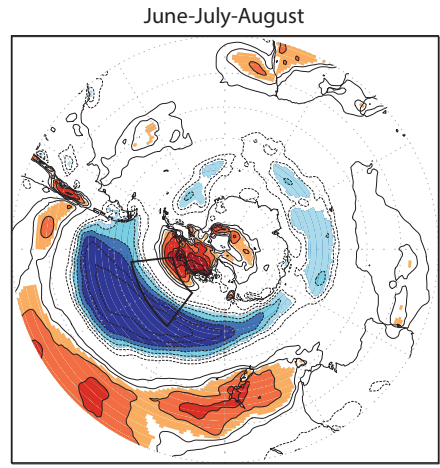

C.

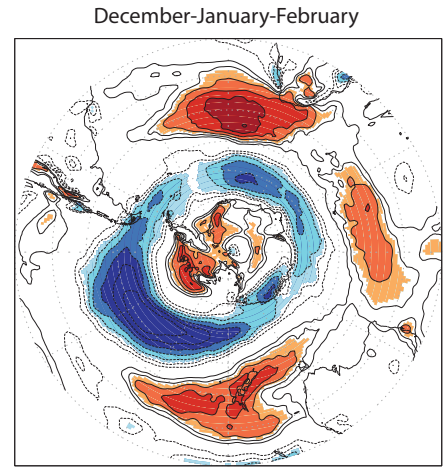

B.

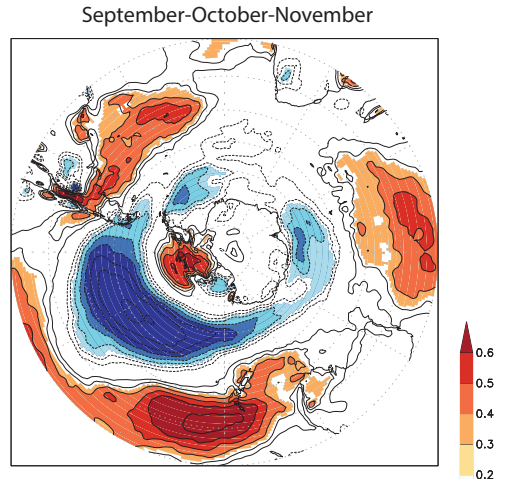

D.

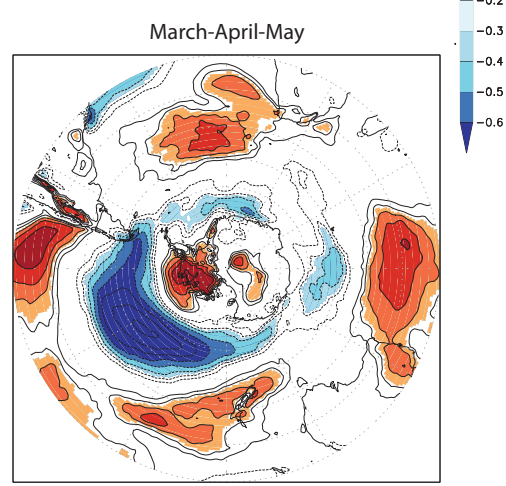

Figure S6: Spatial correlations between detrended and deseasonalised extracted Amundsen Sea region $\left(\mathrm{AS}^{\circ} \mathbf{7 0}^{\circ}-\mathbf{- 5 5} \mathrm{S}, \mathbf{9 5}^{\circ}-135^{\circ} \mathrm{W}\right)$ mean sea level pressure and hemispheric surface zonal wind stress for austral winter (June-August; Panel A), spring (SeptemberNovember; Panel B), summer (December-February; Panel C) and autumn (March-May; Panel D) using ERA Interim (Dee et al., 5 2011) for the period 1979-2015. Significance $p_{\text {field }}<0.05$. 
A.

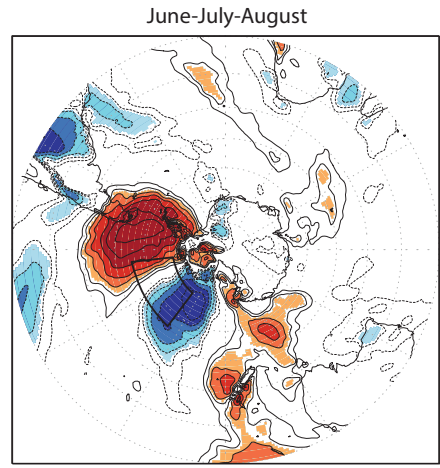

c.

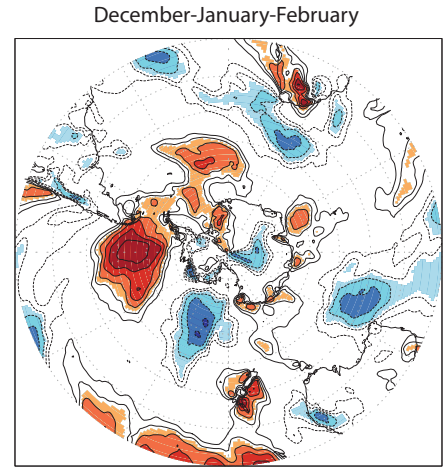

B.

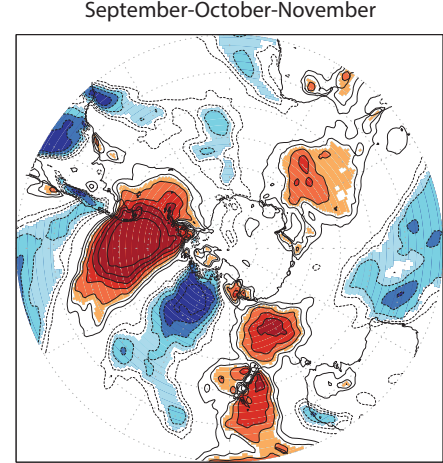

D.

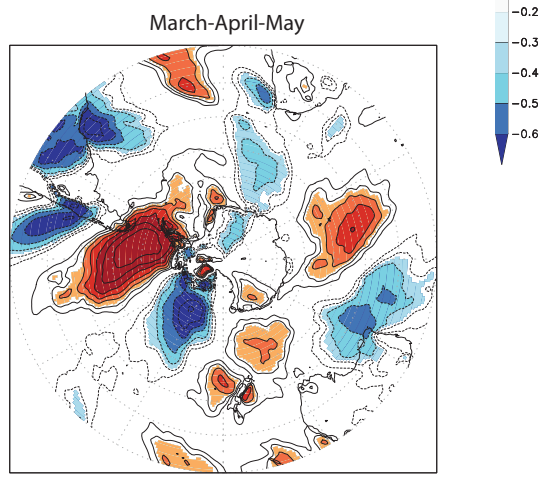

Figure S7: Spatial correlations between detrended and deseasonalised extracted Amundsen Sea region $\left(\mathrm{AS} ; \mathbf{7 0}^{\circ}-55^{\circ} \mathrm{S}, 95-135^{\circ} \mathrm{W}\right)$ mean sea level pressure and hemispheric surface meridional wind stress for austral winter (June-August; Panel A), spring (September-November; Panel B), summer (December-February; Panel C) and autumn (March-May; Panel D) using ERA Interim 5 (Dee et al., 2011) for the period 1979-2015. Significance $p_{\text {field }}<0.05$. 
A.

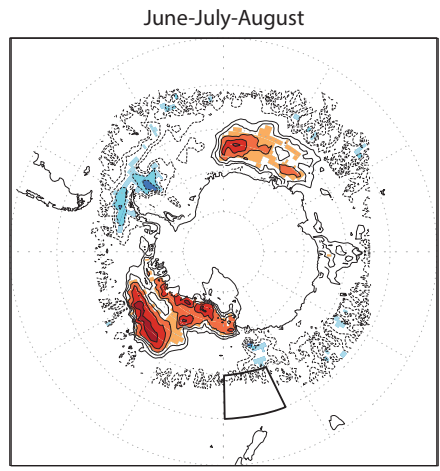

C.

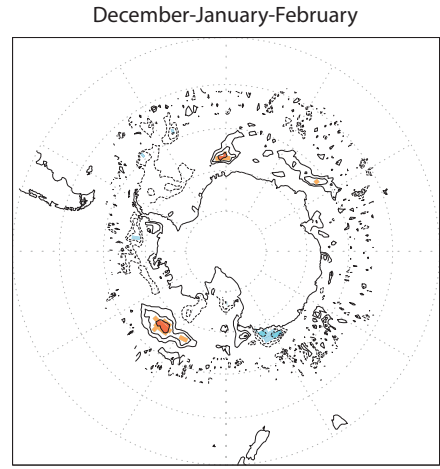

B.
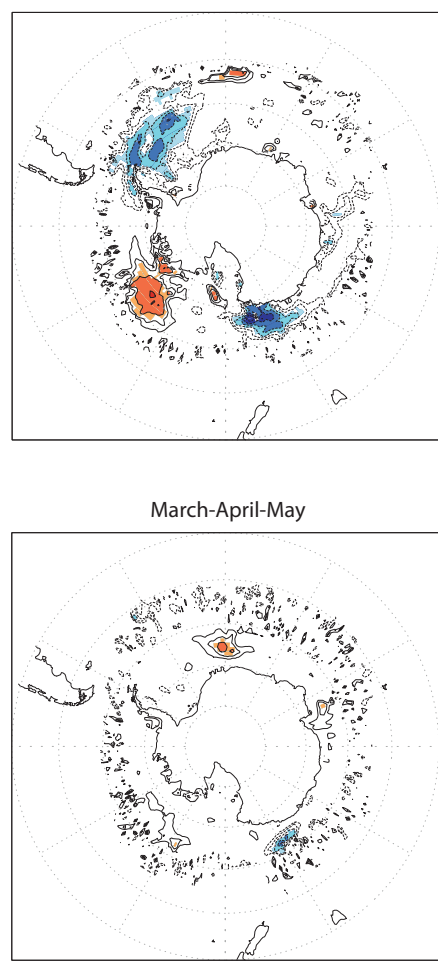

Figure S8: Spatial correlations between detrended and deseasonalised extracted southwest Pacific $\left(\mathrm{SWP}^{\circ} \mathrm{50}^{\circ}-60^{\circ} \mathrm{S}\right.$, 160-180 $\left.^{\circ} \mathrm{E}\right)$ mean sea level pressure and National Snow and Ice Data Center (NSIDC) sea-ice concentration data (https://nsidc.org/data) for austral winter (June-August; Panel A), spring (September-November; Panel B), summer (December-February; Panel C) and autumn (March-May; Panel D) using ERA Interim (Dee et al., 2011) for the period 1979-2015. Significance $p_{\text {field }}<0.05$. 
A.

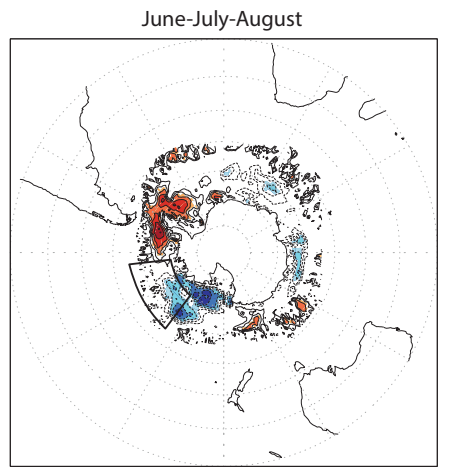

c.

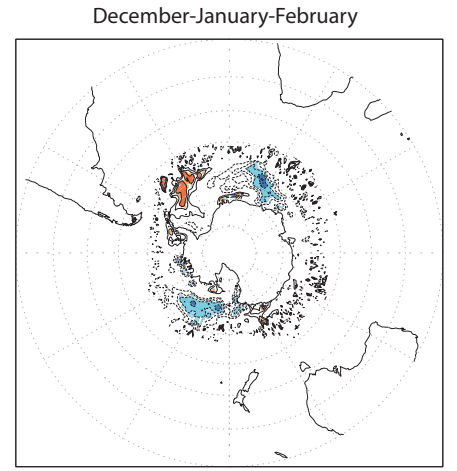

B.
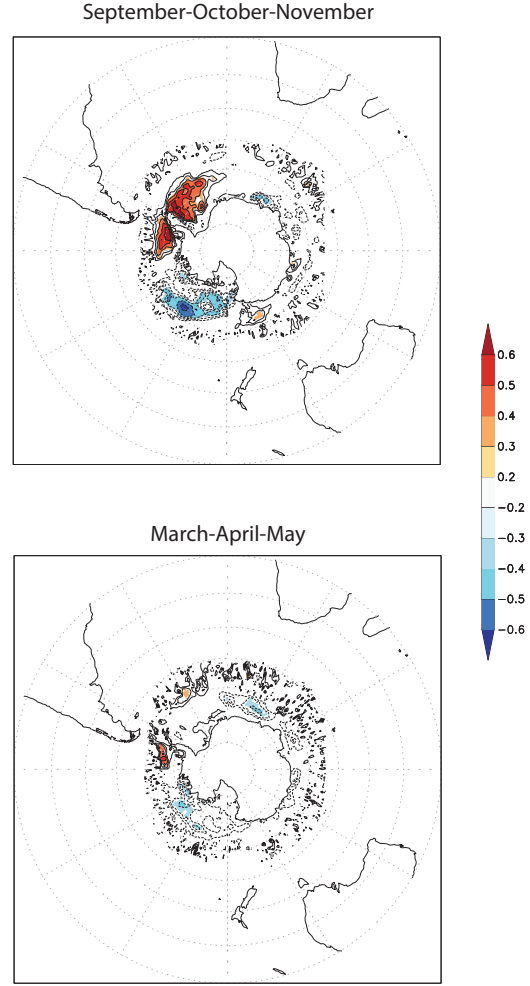

Figure S9: Spatial correlations between detrended and deseasonalised extracted Amundsen Sea region $\left(\mathrm{AS} ; 7^{\circ}-55^{\circ} \mathrm{S}, 95-135^{\circ} \mathrm{W}\right)$ mean sea level pressure and National Snow and Ice Data Center (NSIDC) sea-ice concentration data (https://nsidc.org/data) for austral winter (June-August; Panel A), spring (September-November; Panel B), summer (December-February; Panel C) and autumn (March-May; Panel D) using ERA Interim (Dee et al., 2011) for the period 1979-2015. Significance $p_{\text {field }}<0.05$. 


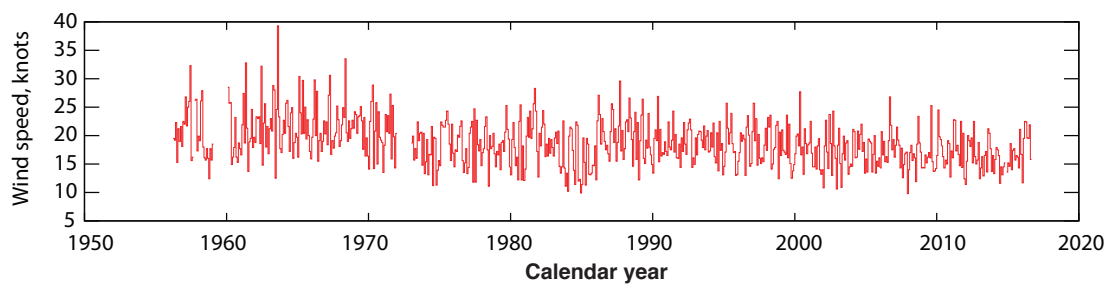

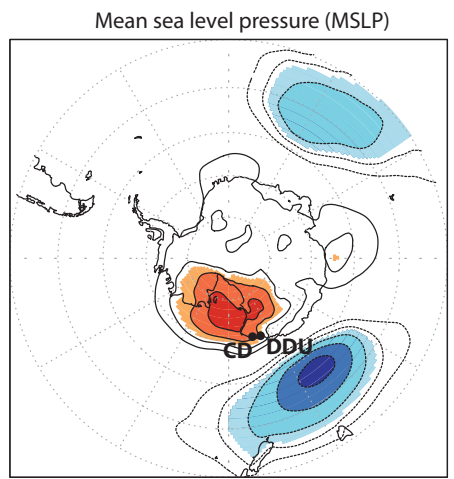

D.

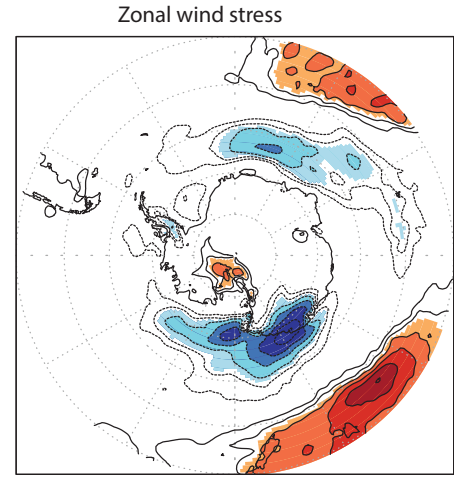

C.

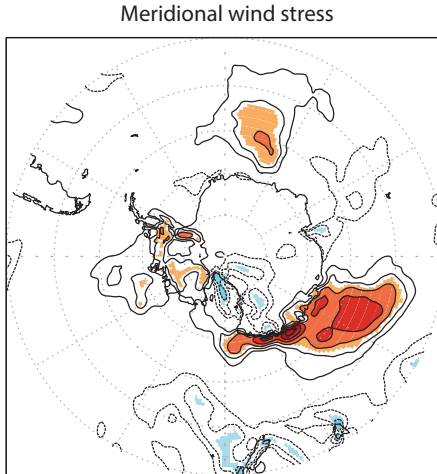

E.

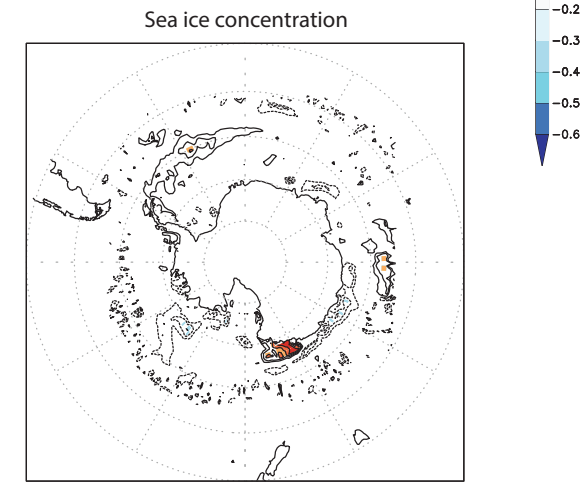

Figure S10: Dumont D'Urville (DDU) monthly-resolved wind speed record (knots; Panel A knots) and detrended and deseasonalised spatial correlation with September-November mean sea level pressure (Panel B), meridional (Panel C) and zonal wind stress (Panel D) from ERA Interim (Dee et al., 2011), and NSIDC sea ice concentration for the period 1979-2015. Significance $p_{\text {field }}<\mathbf{0 . 0 5}$. Location of Cape Denison denoted by 'CD'. 


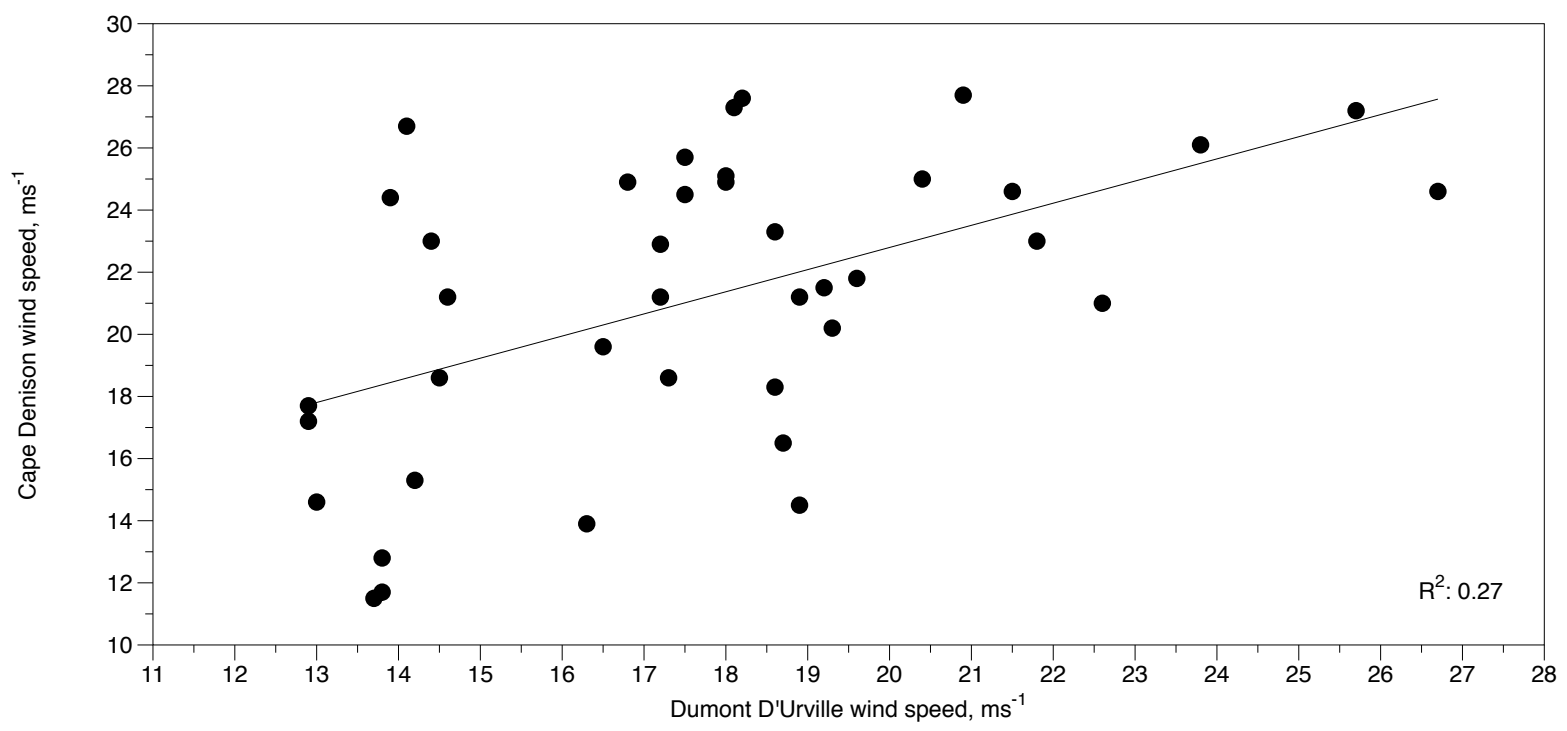

Figure S11: Statistically significant correlation between monthly average wind speeds between Dumont D'Urville and Cape Denison. A description of the dominant katabatic winds across the region are described by Kidson (1946) and Parish and Walker (2006).

A.

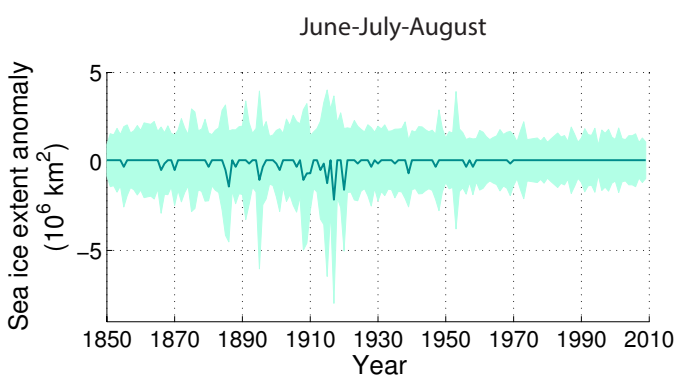

c.

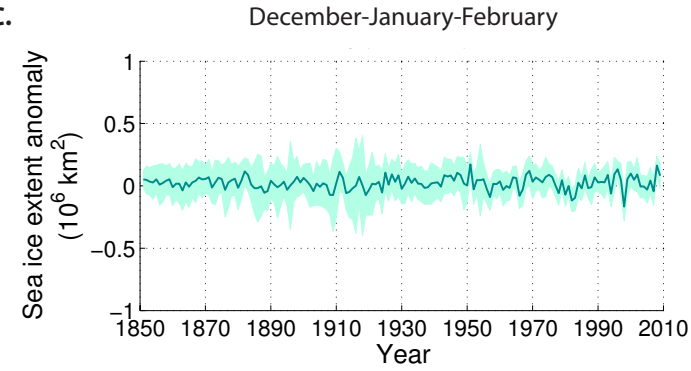

B.

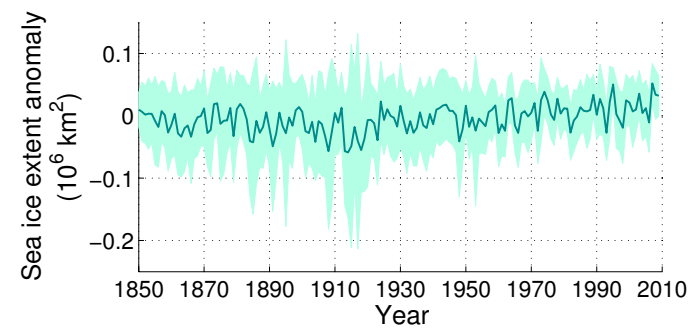

D.

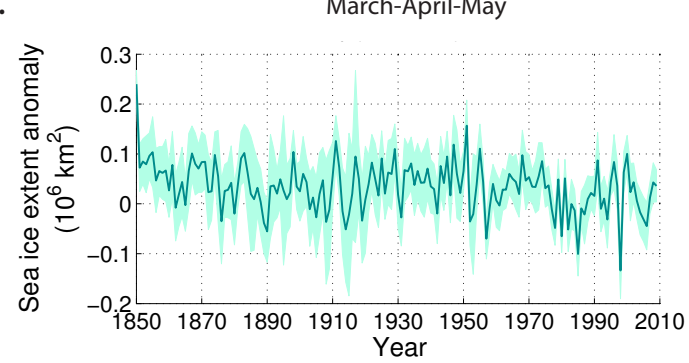

Figure S12: Simulated LOVECLIM changes in sea ice extent (solid green line) with $1 \sigma$ envelope (light green) off George V Land $\left(\mathrm{GV} ; \mathbf{7 0}^{\circ}-60^{\circ} \mathrm{S}, \mathbf{1 5 0}^{\circ}\right.$ to $\left.180^{\circ} \mathrm{E}\right)$ for austral winter (June-August; Panel A), spring (September-November; Panel B), summer (December-February; Panel C) and autumn (March-May; Panel D) (Zunz and Goosse, 2015). 


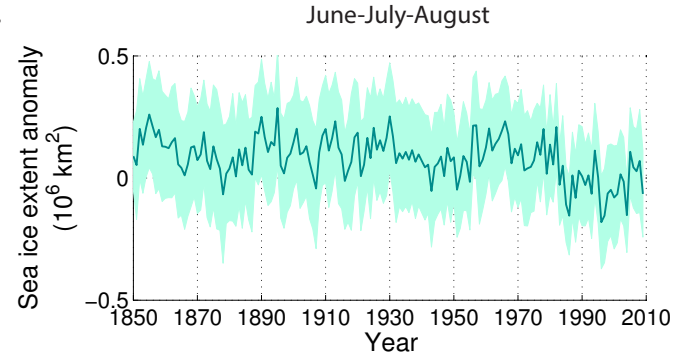

c.

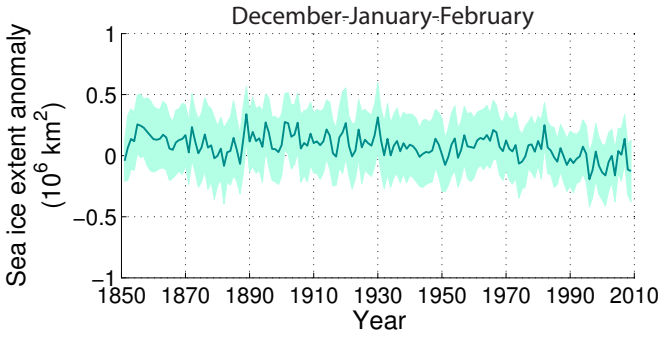

B.
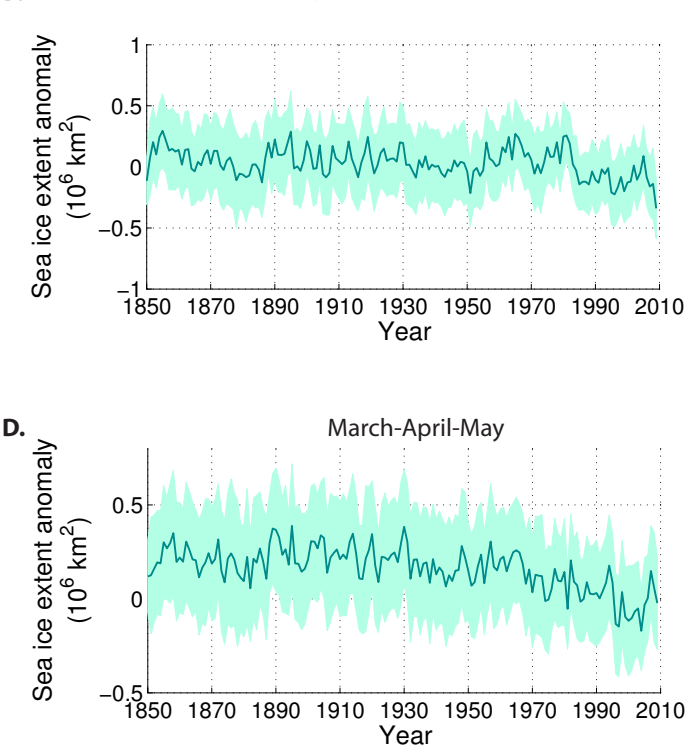

Figure S13: Simulated LOVECLIM changes in sea ice extent (solid green line) with $1 \sigma$ envelope (light green) in the west Amundsen Sea (AS; $7^{\circ}-6^{\circ} \mathrm{S}, \mathbf{1 0 0}^{\circ}$ to $150^{\circ} \mathrm{W}$ ) for austral winter (June-August; Panel A), spring (September-November; Panel B), 5 summer (December-February; Panel C) and autumn (March-May; Panel D) (Zunz and Goosse, 2015). 


\section{References}

Brohan, P., Kennedy, J. J., Harris, I., Tett, S. F. B., and Jones, P. D.: Uncertainty estimates in regional and global observed temperature changes: A new data set from 1850, Journal of Geophysical Research, 111, D12106, 10.1029/2005JD006548, 2006.

Brovkin, V., Bendtsen, J., Claussen, M., Ganopolski, A., Kubatzki, C., Petoukhov, V., and Andreev, A.: Carbon cycle, vegetation, and 5 climate dynamics in the Holocene: Experiments with the CLIMBER-2 model, Global Biogeochemical Cycles, 16, 86-81-86-20, 10.1029/2001GB001662, 2002.

Dee, D. P., Uppala, S. M., Simmons, A. J., Berrisford, P., Poli, P., Kobayashi, S., Andrae, U., Balmaseda, M. A., Balsamo, G., Bauer, P., Bechtold, P., Beljaars, A. C. M., van de Berg, L., Bidlot, J., Bormann, N., Delsol, C., Dragani, R., Fuentes, M., Geer, A. J., Haimberger, L., Healy, S. B., Hersbach, H., Hólm, E. V., Isaksen, L., Kållberg, P., Köhler, M., Matricardi, M., McNally, A. P., Monge-Sanz, B. M.,

10 Morcrette, J. J., Park, B. K., Peubey, C., de Rosnay, P., Tavolato, C., Thépaut, J. N., and Vitart, F.: The ERA-Interim reanalysis: configuration and performance of the data assimilation system, Quarterly Journal of the Royal Meteorological Society, 137, 553-597, 10.1002/qj.828, 2011.

Dubinkina, S., and Goosse, H.: An assessment of particle filtering methods and nudging for climate state reconstructions, Climate of the Past, 9, 1141-1152, 10.5194/cp-9-1141-2013, 2013.

15 Goosse, H., and Fichefet, T.: Importance of ice-ocean interactions for the global ocean circulation: A model study, Journal of Geophysical Research, 104, 23337-23355, 1999.

Goosse, H., and Renssen, H.: A simulated reduction in Antarctic sea-ice area since 1750: implications of the long memory of the ocean, International Journal of Climatology, 25, 569-579, 10.1002/joc.1139, 2005.

Goosse, H., Renssen, H., Timmermann, A., Bradley, R., and Mann, M.: Using paleoclimate proxy-data to select optimal realisations in an 20 ensemble of simulations of the climate of the past millennium, Climate Dynamics, 27, 165-184, 10.1007/s00382-006-0128-6, 2006.

Kidson, E.: Meteorology. Discussions of Observations at Adélie Land, Queen Mary Land and Macquarie Island, Sydney, $121,1946$.

Opsteegh, J. D., Haarsma, R. J., Selten, F. M., and Kattenberg, A.: ECBILT: a dynamic alternative to mixed boundary conditions in ocean models, Tellus A, 50, 348-367, 10.1034/j.1600-0870.1998.t01-1-00007.x, 1998.

Parish, T. R., and Walker, R.: A re-examination of the winds of Adélie Land, Antarctica, Australian Meteorological Magazine, 55, 105$25117,2006$.

Rayner, N. A., Parker, D. E., Horton, E. B., Folland, C. K., Alexander, L. V., Rowell, D. P., Kent, E. C., and Kaplan, A.: Global analyses of sea surface temperature, sea ice, and night marine air temperature since the late nineteenth century, Journal of Geophysical Research: Atmospheres, 108, 4407, doi:4410.1029/2002JD002670, 10.1029/2002JD002670, 2003.

Taylor, K. E., Stouffer, R. J., and Meehl, G. A.: An overview of CMIP5 and the experiment design, Bulletin of the American

30 Meteorological Society, 93, 485-498, 10.1175/BAMS-D-11-00094.1, 2011.

Zunz, V., and Goosse, H.: Influence of freshwater input on the skill of decadal forecast of sea ice in the Southern Ocean, The Cryosphere, 9, 541-556, 10.5194/tc-9-541-2015, 2015. 